


\title{
The police competence to ensure the rights and freedoms of citizens in modern society
}

\author{
DOI: https://doi.org/10.46398/cuestpol.3969.09
}

\author{
Andrii Kubaienko * \\ Ivan Okhrimenko ** \\ Olena Kryzhanovska *** \\ Iryna Kislitsyna **** \\ Maksym Hryshchenko *****
}

\begin{abstract}
The aim of the study is to form a systematic approach to understanding and resolving a set of tasks of police activities that guarantee the rights and freedoms of citizens in modern society. It was concluded that the most typical negligence in this area includes violations of the rights and freedoms of citizens such as the installation of administrative actions against them without any sign of the crime, incorrect characterization of administrative infractions, the violation of the procedural order of administrative detention, cases of unjustified detention without preparation of reports, as well as exceeding the legal deadlines for administrative detention. Particular attention was paid to the set of means of appeal in proceedings concerning administrative offences, which may be referred to as the institution of the protection of citizens' rights and freedoms. Common European approaches to the legal regulation of policing and the influence of European Union law and decisions of the European Court of Human Rights on the guarantee of human rights and freedoms in policing were analyzed.
\end{abstract}

* Candidate in Law, Associate Professor, Associate Professor of the Department of Judicial, Law Enforcement Authorities and Advocacy, National University “Odessa Law Academy”, Odessa, Ukraine. ORCID ID: https://orcid.org/oooo-0002-6648-9764. Email: vz070779@gmail.com

** Doctor in Law, Professor, Professor of the Department of Legal Psychology, National Academy of Internal Affairs, Kyiv, Ukraine. ORCID ID: https://orcid.org/oooo-0002-8813-5107. Email: ivangoo7@ukr.net

*** Candidate in Law, Associate Professor, Lecturer of the Department of Police Administrative Activity, Odessa State University of Internal Affairs, Odessa, Ukraine. ORCID ID: https://orcid.org/ooooooo2-3423-6682. Email: kuganovska82@ukr.net

**** Candidate in Law, Associate Professor of the Department of Judicial, Law Enforcement Authorities and Advocacy, National University “Odessa Law Academy”, Odessa, Ukraine. ORCID ID: https://orcid. org/oooo-0002-7215-0791. Email: kislitsina.ira@gmail.com

***** Candidate in Law, Senior Research Fellow, Leading Inspector of the Nemyshlyany District Department of the Probation Center Branch of the State Institution in the Kharkiv Region, Kharkiv, Ukraine. ORCID ID: https://orcid.org/oooo-0002-6516-671X. Email: maxik_top@ukr.net 
Keywords: administrative law; human rights; rule of law; police; protection of citizens' rights.

\section{Competencia de la policía para garantizar los derechos y libertades de los ciudadanos en la sociedad moderna}

\section{Resumen}

El objetivo del estudio es formar un enfoque sistemático para comprender y resolver un conjunto de tareas de las actividades policiales que garantizan los derechos y libertades de los ciudadanos en la sociedad moderna. Se concluyó que las negligencias más típicas en esta área incluyen violaciones a los derechos y libertades de los ciudadanos como la instauración de acciones administrativas contra ellos sin ningún signo del delito, tipificación incorrecta de las infracciones administrativas, la violación del orden procesal de detención administrativa, casos de detención injustificada sin elaboración de informes, así como por sobrepasar los plazos legales de detención administrativa. Se prestó especial atención al conjunto de medios de apelación en los procedimientos sobre infracciones administrativas, que pueden denominarse la institución de la protección de los derechos y libertades de los ciudadanos. Se analizaron los enfoques europeos comunes a la regulación jurídica de la actividad policial y la influencia de la legislación de la Unión Europea y las decisiones del Tribunal Europeo de Derechos Humanos sobre la garantía de los derechos humanos y las libertades en las actividades policiales.

Palabras clave: derecho administrativo; derechos humanos; imperio de la ley; policía; protección de los derechos de los ciudadanos.

\section{Introduction}

Ensuring human rights and freedoms is a complex task of the state and all its agencies, the content of the public authorities and administration activities, which requires significant financial, material, organizational, legal, scientific, and human resources. This necessitates the scientific development not only of a general model of ensuring human rights and freedoms but also of modifying the activities of individual state structures. Therefore, special attention should be paid to the police activities, vested with broad opportunities and powers in the public sphere. Without maintaining the rights and freedoms of citizens, the activities of public 
authorities and administration, in general, and the police, in particular, do not have any practical significance.

To date, the main legal documents defining the rights and freedoms have been adopted, the relevant standards, which are mainly universal, have been established. However, the compliance with the relevant principles and norms, in particular in law enforcement police activities, is partially reduced in almost all countries owing to some contradictions arising in the process of practical implementation. Thus, the application of legal norms is a legal practice. The validity of the legal decisions is checked by practice through the law requirements; therefore, the law, and ultimately, the practice are the criteria for the correctness of law enforcement acts.

Administrative and legal regulation of ensuring the citizens' rights and freedoms in the police activities are associated with many entities, each of which has its own competence. It must be established that the activities of all subjects involved in the mechanism of ensuring the citizens' rights and freedoms in the police administrative activities are important and the law enforcement process demonstrates their efficiency. The current problems of ensuring and maintaining the citizens' rights and freedoms in police activities are related to the law enforcement activities of the National Police.

An important problem of police activities in modern society is the trust of citizens, as well as their involvement in the field of public order and safety. Despite the fact that this problem has been the subject of scientific analysis, current realities and challenges make us re-evaluate the possibilities of police activities in terms of ensuring the citizens' rights and freedoms to formulate proposals concerning the improvement of its legal and organizational foundations on this basis.

\section{Theoretical framework}

The analysis of scientific publications shows that a significant contribution to the development of the theory of administrative and legal mechanism for ensuring the citizens' rights and freedoms, determining the police competence to ensure the rights and freedoms of citizens in administrative, jurisdictional and permit-based registration activities was presented by Dodin (1985), Gorbunova (2017),), Martynenko (2019), Shoptenko (2017).

The police aspect of ensuring the citizens' rights and freedoms and the legal regulation of police activities to ensure the rights and freedoms of citizens are also presented in the works of such scholars as Aleksandrov, Okhrimenko and Drozd (2017); Bondarenko and Yesimov (2019); Bondarenko (2020); Dorosh and Ivasechko (2017); Fedorenko (2020); 
Kryvolapchuk (2020); Okhrimenko (2020); Shmidt-Assmann (2009); Shvets (2020); Yatsenko (2015).

The analysis of foreign scientific research, such as Birzu (2017); Breetzke, Polaschek and Curtis-Ham (2019); Bufkin (2004); Hoggett (2019); Jones et al. (2011); Mack (1969); Mendel et al. (2017); Schoeman (2002); ZeiglerHill (2017) established that significant changes in modern approaches to police activities necessitate further research on the outlined issues, especially in the content of the police competence to ensure the citizens' rights and freedoms in major areas of professional activity.

Thus, the aim of the study is to form a systematic approach to understanding and solving a set of tasks of the police activities to ensure the rights and freedoms of citizens in modern society. The objectives of the research are to assess the state of modern police activities to ensure the rights and freedoms of citizens, as well as to identify areas for improvement.

\section{Methodology}

The methodological basis of the study was the involvement of systematic and activity approaches, which allowed determining the state of the administrative and legal protection of the citizens' rights and freedoms in the police activities, identifying patterns and relationships of its structural elements, as well as outlining the direction of administrative rules and institutions to achieve the expected results.

The methods of comparative jurisprudence (during the analysis of administrative and legal bases of law enforcement activity of various subjects in the field of ensuring rights and freedoms of citizens), the content analysis of documents, publications of scientists on this subject, formal and logical (for studying legislative and departmental regulations), structural and functional methods, as well as the elements of sociological, historical and axiological methods of cognition were used in the work. These methods allowed identifying the directions and limits of the study, as well as provided an opportunity to expose the problem, to develop the doctrine of administrative and legal rights and freedoms of citizens in the police activities.

The information base of the study consisted of administrative materials of police agencies, court decisions, statistical information, and the results of opinion polls, in particular,

- the assessment of the Ukrainian National Police through a public opinion poll in Kyiv and the regions of Ukraine, conducted from November to December 2018 by Kharkiv Institute for Social Research under the scope of a joint project with the Kharkiv Human Rights 
Andrii Kubaienko, Ivan Okhrimenko, Olena Kryzhanovska, Iryna Kislitsyna y Maksym Hryshchenko

Group "Fight against Tortures, Abusive Treatment, and Lawlessness in Ukraine", supported by the European Union (the total sample size accounted for 19500 respondents) (Summary of the National Report, 2019);

- the report on human rights in the activities of the Ukrainian National Police (Martynenko, 2019).

\section{Results and discussion}

The analysis of the current problems of ensuring the citizens' rights and freedoms suggests that some of them are conditioned by purely objective circumstances. Thus, in particular, normative legal documents in this area outline the ideal model of the citizens' behavior, as well as the standards of administrative activity of authorized state bodies (including the police). Instead, the actual situation happens in a different way, specifically when a particular law enforcer has to operate in unfavorable social and organizational conditions. Such a situation certainly reduces the quality of ensuring the rights and freedoms of citizens to some extent. In this regard, it should be noted that even the most important laws often remain a "dead letter" if there is no mechanism to enforce them.

There is also a problem of a subjective nature, specifically when ineffective protection of the rights and freedoms is directly related to the poor performance of public authorities and administration (Aleksandrov et al., 2017; Kryvolapchuk, 2020). It concerns also the situations when officials do not use the full range of organizational and legal means to ensure the rights and freedoms of citizens for subjective reasons. This problem undermines citizens' confidence in state institutions, and reduces the efficiency of law enforcement activities significantly (Fig. 1).

\section{Figure 1. The efficiency of the police in acting on the cases}

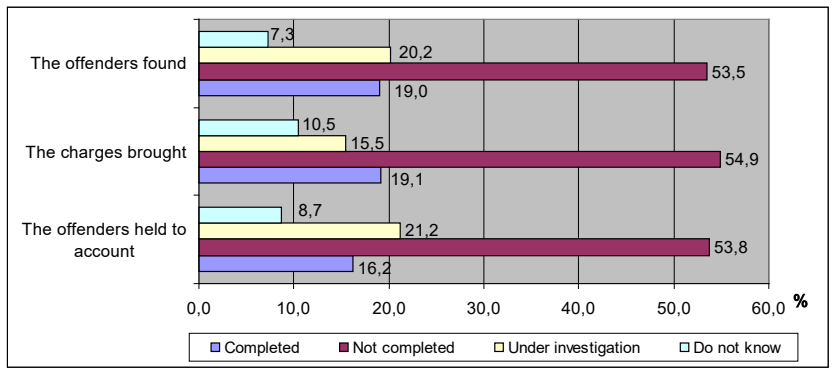

Own elaboration. 
To reduce such cases, it is necessary to improve the law enforcement process, the quality of the qualification subjects that implement relevant regulations, especially in cases where it concerns the rights and freedoms of citizens (Report of the Head of the National Police of Ukraine, 2020).

The bodies of the National Police of Ukraine implement law enforcement activities in a wide range of issues, each of which is directly related to ensuring the rights and freedoms of citizens. One of the most meaningful areas of police work is its administrative and jurisdictional activities, which ensure the solution of a range of tasks related to the application of measures of administrative influence, as well as the protection and defense of human and civil rights and freedoms. However, the administrative-jurisdictional activity cannot exist in isolation from other spheres of administrative work of the police. Moreover, it is logically interconnected with it, while performing a protective function in the respective mechanism.

Examining the content of administrative and jurisdictional activities of the police, it should be noted that its structure includes proceedings on administrative offenses, the application of the various measures of administrative coercion, and the complaints of citizens. These are the main administrative proceedings that determine the quality of the considered activity of the National Police. Thus, there is no doubt that one of the largest and most meaningful administrative proceedings in the police activities is administrative offenses.

Performing the set tasks of law enforcement activity, The National Police agencies implement the main functions: administrative, criminalintelligence, criminally-remedial, executive, preventive, and security. Their legal forms of implementation are conditioned by their immediate purpose, specified in regulations. Analyzing certain administrative and legal norms, one should take account of the regulation of applying administrative penalties and measures to ensure the proceedings on administrative offenses. However, in our opinion, the potential of statutory and regulatory provisions of ensuring the citizens' rights and freedoms are yet to be fully implemented. The law enforcement practice of the police, in the process of which the relevant norms are implemented today, is far from optimal and requires corrective changes to ensure the protection of the rights and freedoms of both participants in administrative proceedings and other persons who are under the law directly or indirectly.

Thus, in particular, according to a survey conducted in NovemberDecember, 2018 by Kharkiv Institute for Social Research under the scope of a joint project with the Kharkiv Human Rights Group "Fight against Tortures, Abusive Treatment, and Lawlessness in Ukraine", supported by the European Union, according to a specially designed sample (a sample included 878 respondents), using the method of personal (faceto-face) interviews, it was found that police officers violated the rights of 
4.6\% respondents and their relatives or did not perform their work well enough during 2018. It should also be noted that $1.7 \%$ of the respondents (326 respondents in a separate sample) stated that they had been victims of beatings, suffering, or tortures by the police officers. At the same time, $90.7 \%$ of persons, who suffered violations of their rights or the rights of their relatives by the police or who noted that the police did not perform well enough, did not file formal complaints. The main reason for this behavior is the opinion that it will be a waste of time (51.4\%) (Summary of the National Report, 2019).

According to the report on human rights in the activities of the National Police of Ukraine for 2019 (Martynenko, 2019), the number of complaints of violations of the citizens' rights and freedoms by police and detection of such violations during targeted activities accounted for 18995. Specifically, 14992 of them were not confirmed, 735 - partially confirmed, and 2093 confirmed.

The analysis of official statistics (Martynenko, 2019) suggests that police officers engage in violation of the citizens' rights and freedoms. In particular, the most typical neglects in this area include such violations of the citizens' rights and freedoms as instituting administrative action against them without any signs of the offense. There are cases of violation of procedural order of administrative detention, drawing up protocols and issuing rulings on administrative offenses without specifying all the necessary information, in addition, there are cases when the procedural rights and obligations of the parties to the proceedings on an administrative offense are not explained, etc.

In addition, significant violations of the citizens' rights during proceedings on administrative offenses may also include incorrect classification of administrative offenses, the violation of the procedural order of administrative detention, cases of unjustified detention without drawing up reports, and exceeding the statutory terms of administrative detention. There are cases of quite a formal exercise of powers by police officers to prove the guilt of persons subjected to administrative liability, to clarify the circumstances that are fundamentally important for resolving a particular case. It is also noteworthy that the police often do not question witnesses, victims, or conduct medical examinations in a designated order (Fig. 2) (Report of the Head of the National Police of Ukraine, 2020).

All these facts mentioned objectively necessitate the need to improve the legal and organizational foundation of the administrative and jurisdictional activities of the police; in addition, the criteria for assessing its efficiency should be changed. In the context of reforming the law enforcement system on the way to European integration, there is a need to include the provisions that would provide citizens with additional guarantees to protect their rights, freedoms and legitimate interests in proceedings on administrative 
offenses in administrative legislation, and to require officials to grant the necessary procedural rights to all the participants of these proceedings.

\section{Figure 2. The respondents' opinion on the need to report on the offense to the police}

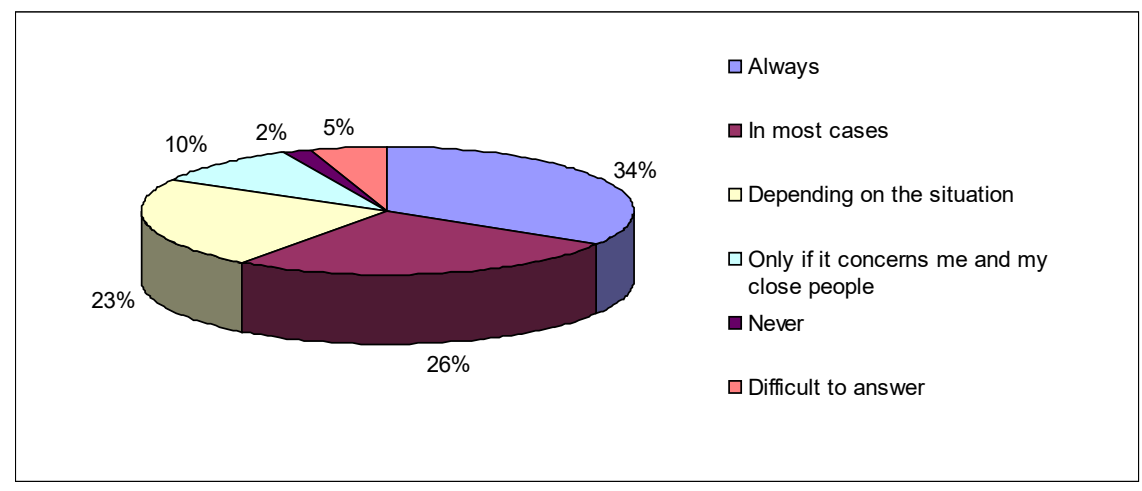

Own elaboration.

Modern legislation embraces not only the material and procedural means and grounds for the application of administrative coercion measures of but it also defines the means of protection that is the institution of appeal. It should be noted that the set of appeals means in proceedings on administrative offenses can be called an institution for the protection of the citizens' rights and freedoms.

The main laws and regulations, maintaining proceedings on citizens' complaints in the National Police agencies, have a number of shortcomings that need to be corrected. Thus, there is a need to review the provisions on the term for filing a complaint against the actions or inaction of a police officer. It results from the fact that after a considerable period of time, it will be very difficult for the officials, conducting the inspection, to investigate all the circumstances of the misconduct and make a sound decision. In addition, faster filing of a complaint will facilitate faster response to illegal actions or decisions, their termination and restoration of rights, freedoms or legitimate interests (Fig. 3) (Report of the Head of the National Police of Ukraine, 2020). 
Andrii Kubaienko, Ivan Okhrimenko, Olena Kryzhanovska, Iryna Kislitsyna y Maksym Hryshchenko

\section{Figure 3. The respondents' opinion on the need to report on the offense to the police}

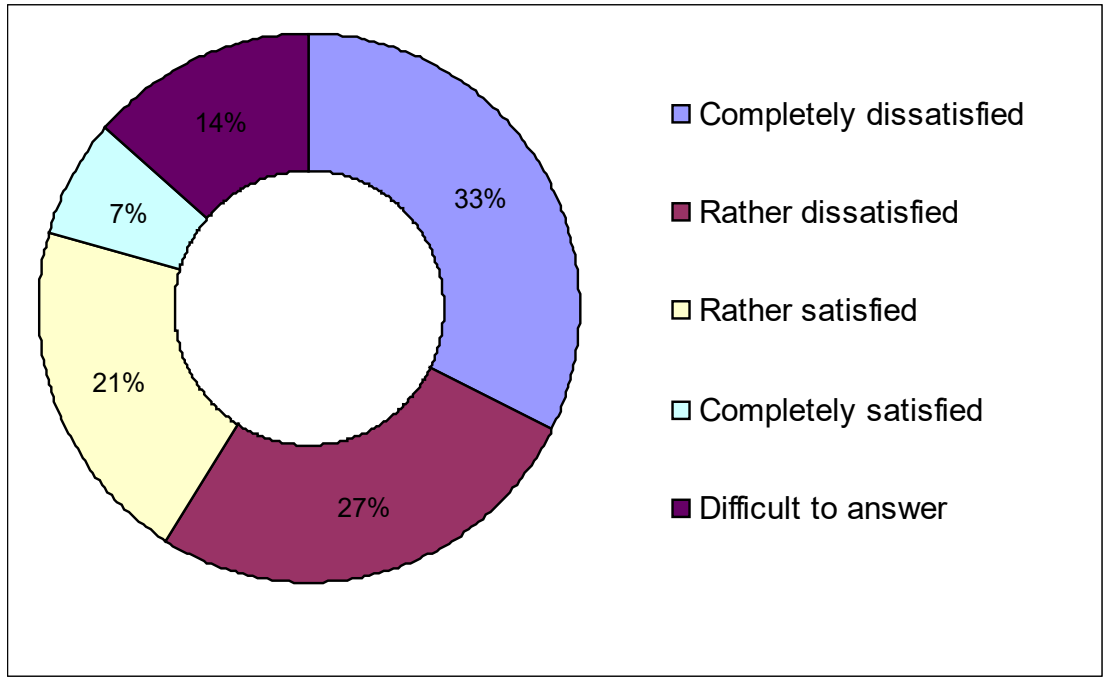

Own elaboration.

The laws and regulations, maintaining proceedings on citizens' complaints in the National Police agencies establish quite clearly the main stages of work with citizens' appeals in general and with complaints in particular, however, there are often cases of formal appeals to certain areas of work. The citizens do not have their legal needs, set out in the complaint, satisfied for subjective reasons. There are still cases when the complaint is considered by a police official, whose action (inaction) is actually being appealed. This state of affairs reduces the law enforcement power of the legal framework that regulates proceedings on complaints and does not help protect the citizens' rights and freedoms.

It should be noted that one of the priorities facing the national law enforcement system today is the implementation of positive experience in ensuring the citizens' rights and freedoms by the police. This requires attention to the peculiarities of the functioning of the foreign police agencies, which have already reformed the legal regulation of their activities taking into account the requirements of the case law of the European Court of Human Rights, which helped increase the efficiency of ensuring the citizens' rights by the police. 
The main task of European Union law is the protection of human rights, which is confirmed by a constituent act binding on all member states - the Charter of Fundamental Rights of the European Union of 7 December 2000 (European Union Charter of Fundamental Rights, 2000). In addition to the rights that become classic in science and practice, this document specifies in detail a number of human rights that are directly related to the activities of the police agencies. Among them, in particular, is the prohibition of tortures (Art. 4); the respect for private and family life (Art. 6), the protection of personal data (Art. 7); the right of access to documents (Art. 42), a number of rights in the field of justice that are partially exercised in administrative proceedings (the right to an effective appeal and access to an impartial trial (Art. 47), the presumption of innocence and the right to a defense) (Art. 48), the principles of proportionality in determining crimes and punishments (Art. 49), etc.

Today, the European legislative body is concerned about ensuring the rights and freedoms of citizens in police activities, as evidenced by the cooperation of the police of the European Union member states within the Schengen Information System, Europol, and other structures (Dorosh and Ivasechko, 2017).

The Convention on the Establishment of Europol of 26 July 1995 addresses the issue of ensuring the rights of citizens within the activities of this supranational body: the protection of personal data (Art. 14), access to personal information stored in the Europol information system (Art. 19), the person's right to correct one's personal information stored in the system (Art. 20), etc. (Reshenie, 2009).

European Union law contains general rules concerning the protection of the citizens' rights in the activities of public authorities and relevant acts concerning the protection of citizens' rights in the process of interaction between the police authorities of the member states. Nevertheless, the amount of normative material in the field of ensuring the citizens' rights in the police activities at the level of European Union law is insignificant, as the competence on these issues remains at the national level (Bondarenko and Yesimov, 2019).

The situation is different in terms of the law of the Council of Europe, which, owing to the binding jurisdiction of the European Court of Human Rights (ECtHR), made it possible to apply international legal obligations under the national legal system even in the field of police activities.

In addition to the case law of the ECtHR, which is one of the factors changing the national legal system in matters of ensuring the citizens' rights in the police activities, there is also the law of the Council of Europe, which concerns the protection of human rights in police activities. Moreover, it applies not only to the police activities of European countries but it is also important for Ukraine as a member of the Council of Europe. 
Despite its recommendatory nature, the European Code of Police Ethics, developed by the Committee of Ministers of the Council of Europe, is a very substantial act of the Council of Europe. The act establishes the general principles of the police activities and ensuring the citizens' rights. This act defines the concept of the police activities (para. 1); the principle of legitimacy in the police activities (para. 2-6); the place of the police in the structure of public authorities (para. 7-11); the organizational bases of police activities, including training of personnel, the rights of police officers (para. 12-34); the guidelines for police activities related to searches, arrests, investigations (para. 35-58); the control over police actions (para. 59-63); the international legal cooperation of police bodies (para. 64-66) (European Code of Police Ethics. Recommendation, 2001).

It should be noted that the case law of the European Court of Human Rights is extremely important for the regulation of ensuring the citizens' rights and freedoms in the activities of the European Union police. The text of the Convention underwent some changes concerning case law. Thus, the interpretation of Art. 6 of the European Convention for the Protection of Human Rights and Fundamental Freedoms by the European Court of Human Rights made it possible to apply the requirements of a fair trial, which were initially used only in judicial proceedings, to the activities of police bodies. The application of the principles of justice in the administrative and law enforcement activities of the police uses modern trends in law-making of any member state of the European Union that allows ensuring the fundamental rights and freedoms of citizens in the activities of the police.

Certain administrative proceedings (in particular, the proceedings on administrative offenses) came to be considered by the European Court of Human Rights as criminal rather than administrative proceedings that led to the need to implement special judicial grants of the rights for persons involved in these proceedings. The European Court of Human Rights recognized confiscation of a driver's license as an administrative penalty; administrative penalties in the form of forfeits and fines imposed on citizens in the field of tax legislation; administrative penalties applied by the bodies responsible for enforcing the sentences of people deprived of their liberty; administrative sanctions imposed by customs authorities in terms of proceedings on offenses in the customs sphere as the administrative proceedings of national legal systems. The jurisdiction of the European Court of Human Rights (Case of "Gradinger v. Austria", 1995) shows that administrative proceedings (the proceedings on administrative offenses, the certain types of licensing activities of the European countries' police agencies) are types of court proceedings, applying the requirements of the Art. 6 of the Convention on the Protection of Human Rights and Fundamental Freedoms of 1950, therefore, they concern the basic rights and freedoms of citizens. 
Concerning the autonomy and lateral interpretation of the Convention on the Protection of Human Rights and Fundamental Freedoms, the European Commission of Human Rights enabled the European Court of Human Rights to impose the liabilities for applying judicial procedural guarantees of human rights in administrative proceedings on the European Council member states. The specific examples can be found in the legislative acts regulating the interrelationships among the administration and citizens. For instance, familiarization with the duties of the French administration in terms of interaction with citizens defines clear signs of applying procedural mechanisms of the judiciary in the administrative law, in particular, the requirements of the transparency of the administrative proceedings, which simulate the analogic principle of the judiciary, the publicity principle.

It can be stated that the citizens' right to correct the information concerning them is the right of defense. The French legislature created the requirements for the data interchange among the administration and citizens within the administrative proceedings that is a copy of the judicial adversarial principle. The other examples of the French administrative proceedings also indicate that at the present stage of the administrative law development, following the principles of the foreign judiciary systems is a common phenomenon aimed at increasing the guarantees of citizens' rights in the activities of police bodies.

Germany has a similar experience. The criteria for performing public administration form "normative guidelines of public administrative activity", aimed at the correctness of the definition that goes beyond legitimacy: equality, responsibility, efficiency, transparency, acceptability, etc. They are the guarantees of the rationality of the public administration activity. Regarding the development history, they are enriched by the idea of law and the experience of general considerations of justice and practicality, which the practice of substantiation of other legal systems defines more clearly (Shmidt-Assmann, 2009).

Therefore, having implemented the requirements of the case law of the European Court of Human Rights for applying the basic jurisdictional principles within the administration activities into the administrative and legal regulation of the police activities, the legislation of some European countries contributed to the increase in the level of the citizens' rights in the police activities.

We cannot but agree with the professor Ye. Dodin (1985) that the administrative and jurisdictional activities are an integral part of the administrative activity of the internal affairs agencies and, correspondingly, they have the same features. Besides, administrative and jurisdictional activities have some peculiarities defining them as a separate kind of administrative activity. 
If one classifies jurisdictional activity of the National Police of Ukraine by such criteria as character, peculiarities, and the complexity grade of the questions of fact of administrative offenses and the complexity of the jurisdictional procedure related to it (that is its volume and borders), the idea of O. Gorbunova (2017) should be taken into consideration to classify the administrative and jurisdictional proceedings in the National Police of Ukraine in the following way: a) general (complete) proceeding; b) summary (speedy) proceeding; c) complex (expanded) proceeding; d) proceedings of the authorities of the second instance (i. e. a higher-ranking official, in comparison to the employee who considered the materials of the administrative case initially).

The proceedings on the citizens' complaints are one of the major ways of protecting the citizens' rights, freedoms, and legal interests from any illegal actions by police officers. The basis for initiating such proceedings is filing a complaint of the rights violation and the requirement to restore them and punish the guilty employees to the head of the police agency or unit.

We cannot but agree with S. Shoptenko (2017) on the relevance of setting the standards concerning the fact that a complaint of the officials' actions or inaction violating the rights or freedoms of citizens, or limiting their realization, can be filed to the agency or a high-ranking official within a month from the date of their commission. At the same time, it is necessary to enshrine the right of the head of the police body to extend this period if there are significant reasons for missing it.

Besides, the provisions on responding to the complaint need to be supplemented. The law provides that a written or oral response is sent to a person (at his/her request). However, the person's preference for the form of the response is not specified anywhere. In effect, a written response is usually provided for written complaints, and an oral response - for oral complaints if the complaint does not require lengthy detailed consideration. In the latter case, the response can be given in both forms. Such an order should be enshrined in law. In addition, it is necessary to determine the procedure for responding to the electronic complaint and its form.

To remedy the situation, in our opinion, it is necessary to create public commissions to deal with citizens' complaints. These commissions could work with citizens' requests challenging the actions or inaction of police officials. The human rights activists could also be engaged in such commissions, as well as various civil society institutions that are interested in the relevant work. This approach will eliminate corporate solidarity in dealing with complaints; improve the quality of work with citizens' requests. All this will help protect the rights and freedoms of citizens in the field of police activities, it will also increase the responsibility of police officials, in addition, it can contribute to the level of legitimacy and discipline in the system of the National Police of Ukraine. 
O. Yatsenko's (2015) remark about the imperfection of providing administrative services by police units, which arises on the basis of numerous gaps and legal conflicts in the legislation, is relevant. Thus, according to Art. 178 of the Civil Code of Ukraine, weapons and other items covered by the authorization system are classified as objects restricted in civil circulation. Instead, according to para.13, part 2, Art. 2 of the Law of Ukraine "On Administrative Services" of o6 September 2012, its effect does not extend to the relationship of rights acquisition in respect of the objects restricted in civil circulation.

Therefore, the shortcomings of the current regulations lead to the ambiguity in the firearms circulation that is a prerequisite for violations in this area and results in the increased rates of crimes with the use of weapons. In addition to the analyzed shortcomings, a number of questions about the legitimacy of the establishment of the list of documents required for providing these services, deadlines for re-registration of weapons, related costs, etc. by the departmental regulations of the Ministry of Internal Affairs of Ukraine. It is important to note that Ukraine remains the only European country where the issue of the firearms purchase, possession, employment, and the control of firearms circulation is not regulated by law. This fact is a significant shortcoming in the sphere of legal regulation of the authorization system, which leads to a violation of the rights and freedoms of citizens in the registration and permitting activities.

The development of legal regulation of police activities in terms of ensuring human and civil rights and freedoms in the European Union is a natural consequence of the competition of divergent interests of the state and civil society, expressed in the formation of a complex system, the elements of which along with state legal law act, supplement, correct, and sometimes actually replace its forms of non-state social law (primarily, customary, corporate and municipal law). The European legislation included the requirements of the case law of the European Court of Human Rights on applying basic principles of justice within the administration activities in the administrative and legal regulation of police activities, which helped to increase the protection of citizens' rights in the police activities. The interaction between the European Court of Human Rights and national judicial jurisdictions is conditioned by the essence of the process and its values developed by the historical development of the right to a fair trial, which, in turn, has not been granted by the European Convention on Human Rights, but has originated in national jurisdictions in an evolutionary way long before the adoption of the Convention. To date, it is enshrined as a universally recognized principle of international law, while remaining the national law at the law enforcement level. 
Andrii Kubaienko, Ivan Okhrimenko, Olena Kryzhanovska, Iryna Kislitsyna y Maksym Hryshchenko

178

The police competence to ensure the rights and freedoms of citizens in modern society

\section{Conclusions}

The conducted analysis states that the administrative and jurisdictional activity of the police is performed by means of the material and procedural forms established by the law. Ensuring the rights of citizens by the police is carried out through the use of various methods. These methods relate to the quality of the administrative activities of the police, therefore, their improvement directly affects the efficiency of the administrative and jurisdictional activity of the police in the field of ensuring and protecting the rights of citizens.

The activities of the police, which are carried out in the administrative and legal sphere, are grounded on certain basic requirements that do not allow going beyond the established limits. The basic regulations also largely determine the quality of the public authorities' work that ensures the citizens' rights and freedoms. Such basic prescriptions are the principles of legal regulation, which determine the efficiency of the administrative and jurisdictional activities of the police in the field of ensuring the rights and freedoms of citizens. Thus, the administrative activity of the police is based on principles, each of which plays its role in its organization and in ensuring the rights and freedoms of citizens. Improving the efficiency of the administrative activities of the police is possible through the comprehensive implementation of these principles, which in the future will be reflected in positive results in the field of protection of the citizens' rights and freedoms.

On the basis of the results obtained, it should be noted that the national administrative legislation in the field of arms trafficking and private detective work is not established firmly that does not allow using the power of the National Police completely to ensure the rights and freedoms of citizens in these areas of public relations. The analysis of the foreign practice of administrative and legal regulation of this area gives grounds to argue that there is a need to enshrine such areas of human rights advocacy of the police as control over compliance with the authorization system and security activities, as well as the formation of appropriate functional, organizational, personnel and financial basics of exercising such powers.

It should be noted that improving the efficiency of the police activities in the field of ensuring the citizens' rights and freedoms is possible through the improvement of legislation and, in particular, through the implementation of the case law of the European Court of Human Rights.

The development of police interaction with public associations and other civil society institutions can be a promising way to improve the protection of citizens' rights and freedoms in the police activities. The highest priority should be the rejection of the established quantitative indicators in the work of the police. We should stop chasing the number of reports on administrative offenses, the number of detained for various offenses, 
comparing the available indicators with the same period last year, etc. New criteria for the police evaluation are needed. It should be emphasized that such an approach generally contributes to the falsification of reporting, the substitution of facts, misleading both the country's leadership and citizens about the real level of law enforcement.

\section{Bibliographic References}

ALEKSANDROV, Dmytro; OKHRIMENKO, Ivan; DROZD, Olexiy. 2017. "Features of professional-psychological adaptation of employees of the National Police of Ukraine to law enforcement activities" In: Science and Education. Vol. 11, pp. 35-45.

BIRZU, Bogdan. 2017. "Europol objectives and tasks in the construction of the European Union” In: Some critical opinions and proposals. Juridical Tribune (Tribuna Juridica). Vol. 7, No. 1, pp. 157-166.

BONDARENKO, Volodymyr; YESIMOV, Serhiy. 2019. "Legal regulation of police activities concerning the promotion of rights and freedom of man and citizen in the European Union countries" In: Social \& Legal Studios. Vol. 2, No. 4, pp. 3-10.

BONDARENKO, Volodymyr. 2020. "Professional Skills and Competencies of the Future Police Officers" In: International Journal of Applied Exercise Physiology. Vol. 9, No. 5, pp. 35-43.

BREETZKE, Gregory; POLASCHEK, Devon; CURTIS-HAM, Sophie. 2019. "Does crime count? Investigating the association between neighborhoodlevel crime and recidivism in high-risk parolees" In: Applied Geography. Vol. 102, pp. 20-27.

BUFKIN, Jana. 2004. "Criminology/criminal justice master's programs in the United States searching for commonalities" In: Journal of Criminal Justice Education. Vol. 15, No. 2, pp. 239-620.

EUROPEAN COURT OF HUMAN RIGHTS. 1995. Gradinger v. Austria: Judgment (Application no. 15963/90). Available online. In: http:// hudoc.echr.coe.int/fre?i=001-57958. Consultation date: 11/12/2020.

DECISIONNo. 2009/371/PVDOFTHECOUNCILONTHEESTABLISHMENT OF THE EUROPEAN POLICE OFFICE. 2009. Legislation of Ukraine. Available online. In: https://zakon.rada.gov.ua/laws/show/994_a78. Consultation date: 11/12/2020. 
Andrii Kubaienko, Ivan Okhrimenko, Olena Kryzhanovska, Iryna Kislitsyna y Maksym Hryshchenko

DODIN, Evheniy. 1985. Evidence in the administrative and jurisdictional activities of law enforcement agencies. Kyiv, Ukraine.

DOROSH, Larysa; IVASECHKO, Olexiy. 2017. "Features of functioning and challenges of EU development in the near future (2017-2018)" In: Humanitarian Vision. Vol. 3, No. 1, pp. 19-24.

COMMITTEE OF MINISTERS. 2001. Recommendation of the Committee of Ministers to Member States on the European Code of Police Ethics. Available online. In: https://www.openpolice.ru/docs/evropejskijkodeks-policejskoj-etiki/. Consultation date: 11/12/2020.

EUROPEAN UNION CHARTER OF FUNDAMENTAL RIGHTS. 2000. Legislation of Ukraine. Available online. In: https://zakon.rada.gov.ua/ laws/show/994_524. Consultation date: 11/12/2020.

FEDORENKO, Olexandr. 2020. "Coping Behavior of Criminal Police Officers at Different Stages of Professional Activity” In: BRAIN. Broad Research in Artificial Intelligence and Neuroscience. Vol. 11, No. 2, pp. 124-146.

GORBUNOVA, Olga. 2017. "Administrative andjurisdictional activity of Ukraine National police". In: International Scientific Journal "Internauka". Series: "Juridical Sciences" 1 (January). Available online. In: https:// www.inter-nauka.com/en/issues/law2017/1/2747/. Consultation date: $11 / 12 / 2020$.

HOGGETT, James. 2019. "Challenges for police leadership: Identity, experience, legitimacy and direct entry" In: Journal of Police and Criminal Psychology. Vol. 34, pp. 145-155.

JONES, Samuel; MILLER, James; LYNAM, David. 2011. "Personality, antisocial behavior and aggression: A meta-analytic review" In: Journal of Criminal Justice. Vol. 39, No. 4, pp. 329-337.

KRYVOLAPCHUK, Volodymyr. 2020. "Attitude of young people to the criminality problem in Ukrainian postmodern society" In: Postmodern Openings. Vol. 11, pp. 93-115.

VERKHOVNA RADA OF UKRAINE. 2012. On Administrative Services: Law of Ukraine. Available online. In: https://zakon.rada.gov.ua/laws/ show/5203-17. Consultation date: 11/12/2020.

MACK, John. 1969. "Behavior ratings of recidivist and nonrecidivist delinquent males” In: Psychological Reports. Vol. 25, No. 1, pp. 252-260.

MARTYNENKO, Vitaliy. 2019. "Reflected reality: human rights in the police" In: Resonance. Available online. In: http://resonance.ua/vidzerkalena- 
realnist-pro-prava-lyu/. Consultation date: 11/12/2020.

MENDEL, Jonathan; FYFE, Nicholas; HEYER, Garth. 2017. "Does police size matter? A review of the evidence regarding restructuring police organizations" In: Police Practice and Research. Vol. 18, No. 1, pp. 3-14.

OKHRIMENKO, Ivan. 2020. "Police Training or Police Education: View on the Matter" In: International Journal of Applied Exercise Physiology. Vol. 9, No. 12, pp. 129-136.

REPORT OF THE HEAD OF THE NATIONAL POLICE OF UKRAINE. 2020. The results of the work of the department in 2020. Avaliable online. In: https://www.npu.gov.ua/assets/userfiles/files/zvity/zvit-npu-za2020-rik_com.pdf. Consultation date: 11/12/2020.

SCHOEMAN, Mikle. 2002. "A classification system and an inter-disciplinary action plan for the prevention and management of recidivism". University of Pretoria. Pretoria. South Africa.

SHMIDT-ASSMANN, Edgar. 2009. "General administrative law as the idea of regulation: thebasic principles and objectives of systematization of administrative law". Kyiv, Ukraine.

SHOPTENKO, Sofia. 2017. "Problems of normative-legal regulation of proceedings on citizens' complaints in the bodies of the National police of Ukraine" In: Comparative Analytical Law. Vol. 6, pp. 292-295.

SHVETS, Dmytro. 2020. "The new police training system: Psychological aspects" In: Postmodern Openings. Vol. 11, pp. 200-217.

SUMMARY OF THE NATIONAL REPORT. 2019. Evaluation of the activities of the National Police of Ukraine by means of a public opinion poll. Available online. In: http://khpg.org/index.php?id=1550061985. Consultation date: 11/12/2020.

YATSENKO, Olga. 2015. "Certain problems oflegal regulation of administrative services provided for by internal affairs bodies" In: Scientific Bulletin of Uzhgorod National University. Law Series. Vol. 34, No. 2, pp. 158-161.

ZEIGLER-HILL, Virgii. 2017. "Pathological personality traits and criminogenic thinking styles” In: Personality and Individual Differences. No. 110, pp. 41-48. 
Vol. 39 N $^{\circ} 69$

Esta revista fue editada en formato digital y publicada en julio de 2021, por el Fondo Editorial Serbiluz, Universidad del Zulia. Maracaibo-Venezuela 